\title{
Finny Merchandise: The Atlantic Cod (Gadus morhua) Trade in Gold Rush-Era San Francisco, California
}

CYLER CONRAD, Department of Anthropology, University of New Mexico, Albuquerque, NM, 87131, and Environmental Protection and Compliance, Los Alamos National Laboratory, USA.

Email:cylerc@unm.edu

UPULI DESILVA, Department of Anthropology, University of California, Irvine

BRITTANY BINGHAM, Department of Anthropology, University of Kansas

BRIAN M. KEMP, Department of Anthropology and Laboratories of Molecular Anthropology and Microbiome Research, University of Oklahoma

KENNETH W. GOBALET, Department of Biology, California State University, Bakersfield

KALE BRUNER, Department of Anthropology, University of Kansas

ALLEN G. PASTRON, Archeo-Tec: Consulting Archaeologists, Oakland, CA

During California's Gold Rush of 1849-1855, thousands of miners rushed to San Francisco, Sacramento, and elsewhere throughout northern California, creating a significant demand for food. Here we investigate the role of Atlantic cod (Gadus morhua) and Pacific cod ( $G$. macrocephalus) during the Gold Rush era using historical records, ancient DNA, and vertebral morphology in the cod assemblage recovered from Thompson's Cove (CA-SFR-186H), a Gold Rush-era site in San Francisco. From the 18 cod bones recovered from Thompson's Cove, our analysis of five specimens for ancient DNA indicates that Atlantic cod were imported during the 1850s, likely as a (largely) deboned, dried and salted product from the East Coast of the United States. Curiously, while locally available in very deep waters off the California coast, Pacific cod were minimally fished during the 1850 s and became abundantly available in the 1860 s after an Alaska-based fishery developed.

Key words: Cod, Gadus morhua, Gadus microcephalus, Gold Rush, San Francisco, ancient DNA, zooarchaeology

During the first year of California's Gold Rush (1848-1849), the small town of Yerba Buena (later renamed San Francisco) experienced an influx of people and grew from approximately 800 residents to well over 20,000 (Bancroft 1888:158; Soulé et al. 1854:244). Opportunistic argonauts traveled from distant locations to California, including large numbers from the East Coast of the United States. The overwhelming effect of this population movement is clearly reflected in historical accounts and the Gold Rush archaeological record-San Francisco's new population was hungry (Conrad et al. 2015a; Davis 1889; Delgado 1996, 2009; Holliday 1981; Lotchin 1974; Taylor 1868). The influx of migrants resulted in new food-based economic demands which the small community of Yerba Buena and northern California could not readily satisfy based on limited local crop and domestic animal availability during the late 1840s and 
early 1850s (Bancroft 1888; Soulé et al. 1854; Stine 1980). Demand for food quickly led to the creation of a wild game market, exhaustion of locally available wild animals, and the wholesale importation of animals and other food products into this region from around the world. Noteworthy importations included Galapagos tortoises (Chelonoidis sp.), green sea turtles (Chelonia mydas), kangaroos, and Eastern (or Atlantic) oysters (Crassostrea virginica) to San Francisco during the 1850s (Conrad 2017; Conrad and Pastron 2014; Conrad et al. 2015a, 2015b, 2018). The epicures of Gold Rush-era San Francisco also consumed a wide variety of local and imported fishes and other seafood, a clear necessity during this time: herring, sardine, salmon, lobster, mackerel, clam, scallop, shrimp, anchovy, and even swordfish, are documented in early import records (Daily Alta California 1850b, 1850c, 1850e, 1850f, 1850g, 1850h, 1850i, 1851a, 1851b). ${ }^{1}$ An April 5, 1851, account describes this well (Johnston 1964:133):

The fish market that adorns Long Wharf is becoming ornamental as well as useful. In extent, and in the variety of the finny merchandise displayed, it already rivals those of the Atlantic cities. Every description of animal that inhabits our bay may be found spread out on the boards, and so active are their captors, the fishermen, that multitudes of them are yet alive and capable of taking their last look and flopping finally on the famous Long Wharf. Besides a tempting show of salmon and innumerable others of the fish species, are here to be viewed a number of amphibious delicacies, such as turtles, lobsters, crabs, and at times also, scant representatives of the oyster and clam beds, which may assert, are all sufficiently plenty at many points along our coast, and even in the waters of San Francisco bay. This latter idea, by the way, is worthy of fathoming. If so be there are "oysters and clams" in our bay, would it not pay to introduce our citizens to the flavor? However, the fish market on Long Wharf is worthy of examination.

While historical records support a wide diversity of fish and seafood importation into San Francisco, archaeological records are less clear. Gold Rush sites from San Francisco and the Bay Area typically do not have evidence supporting this wholesale import of fish and seafood (Conrad et al. 2015a; Figure 1). Instead, animal remains at these sites tend to be dominated by domesticates, including cattle, pigs, sheep, and chickens; commonly hunted wild game (e.g., deer, elk, ducks/geese); and local fishes (e.g., salmon, steelhead, sturgeon, rockfish; Christenson 1989; Conrad et al. 2015a; Hattori and Kosta 1990; Pastron and Beevers 2003; Praetzellis 2017; Stine 1980; Valente 2012).

Based on these records, we investigate the use of cod (Gadus sp.) at Thompson's Cove, and the implications of the cod trade during the mid-nineteenth century. Historical accounts (Collins 1892) indicate that numerous Atlantic cod (Gadus morhua) were imported into San Francisco during the Gold Rush, but current archaeological records do not support the presence of this fish during the late 1840s to 1850s. In addition, although G. morhua were fished for centuries in the northern Atlantic prior to the onset of California's Gold Rush, Pacific cod ( $G$. macrocephalus) were apparently not utilized in California, based on current zooarchaeological and ethnohistoric data (Gobalet et al. 2004; Mackovjak 2019; Scofield 1954). Pacific cod, however, were exploited by the Native peoples of the Pacific Northwest (Butler and Campbell 2004; McKechnie and Moss 2016; Moss 2011; Tushingham and Christiansen 2015). Although cod are present at Thompson's Cove, previous morphological analyses (Conrad et al. 2015a) did not distinguish between Pacific or Atlantic cod based on skeletal elements because of the lack of comparative skeletons of both species. Now, with appropriate comparative skeletal and ancient 
DNA analysis we examine the species of cod present in Gold Rush-era San Francisco and the relationship between cod and broader fish consumption during this time.

\section{THE GOLD RUSH-ERA ATLANTIC COD TRADE AND FISH EXPLOITATION} During and prior to the California Gold Rush, maritime passengers suffered from a lack of fresh foods on long voyages. Passengers often complained about the poor quality and repetitiveness of salted and dried meats and hard tack, which remained preserved but were bland and lacked adequate nutrients (Delgado 1996; Pomfret 1954). Commonly, these salted meats included beef and pork, but records also indicate the use of salted cod (Figure 2), either as a primary maritime staple or an imported market item (Lewis 1949). As an example, on February 19, 1850, the ship Carthage arrived in San Francisco with a full cargo of building materials and food products, including "codfish" (Daily Alta California 1850a). Even prior to the onset of the Gold Rush, in 1848, newspaper records document the import of "Cod Fish" into San Francisco (The Californian 1848). A US fisheries report summarized this Gold Rush era by stating that prior to 1863, all cod imported to California was "of the salt-cured" form, derived from Atlantic stocks; these salted fish were transported "across the Isthmus" (of Panama) or around Cape Horn to San Francisco at great cost and often were damaged or spoiled (Collins 1892; Mackovjak 2019:3132). A review of newspaper accounts supports this record and indicates that at least 38 vessels arrived in San Francisco between December 1849 and December 1852 - the height of the Gold Rush - importing 1,228 boxes, 382 drums (i.e., wooden barrels) and 100 half drums, 190 cases, 70 casks, 28 large casks (or "hhds"), 89 tubs, 49 barrels, and 12 half barrels of "codfish," along with 18 kegs of "codfish tongues" and 22 boxes of "cod liver oil" (Table 1). For the 1,228 boxes of codfish alone, assuming a conversion of $\sim 70-140 \mathrm{lb}$ of fish per box (see Waterman 1969), this suggests at a minimum between 85,960 and 171,920 lb of cod were imported during 1849-1852. These vessels sailed from home ports in the Atlantic, including Boston, New Bedford, New Haven, and New York; New Orleans; and several vessels from England, Australia, and elsewhere (Table 1), suggesting the large demand for imported foodstuffs resulted in Atlantic cod arriving from both primary (e.g., Boston) and secondary (e.g., Australia) maritime codfish markets.

Newspaper accounts are also supported by company correspondence dating from this period. For example, a letter of May 15, 1855, from a commercial mercantile house in San Francisco makes note of written correspondence with an associate in Sydney, Australia, about the possibility of importing various items, including cod: "Codfish we see quoted very low. This is a delicate article, but if you find it perfect and dry, with no appearance of moisture whatever, fish white $\&$ good, free from strong smell \& could ship by a dry vessel in a dry place, it would probably come good and command 6.2-7.2 cts. on arrival" (Crosby \& Dibblee 1855).

Oddly, although these written accounts document an abundance of cod imported into San Francisco during the Gold Rush, archaeological records present a different story. Gold Rush sites in San Francisco and the Bay Area tend to be represented by local fishes, or fishes brought into the city from the California coast or the Sacramento-San Joaquin delta (Conrad et al. 2015a; Table 2). For cod, the earliest Gold Rush archaeological evidence occurs at Thompson's Cove and a site in Sacramento, the Golden Eagle Hotel (Praetzellis et al. 1980; Schulz 1980). These physical records are notably rare.

For example, at the Hoff Store site, which burned in the fire dated to May 3-4, 1851, in downtown San Francisco, zooarchaeological and artifact evidence support the importation of packaged or "salt-pork," canned oysters, and sardines (Hattori and Kosta 1990), the only fish. At a comparable warehouse site at 343 Sansome Street, which also burned in the fire, the majority 
of faunal remains represented domesticated species_cattle (Bos taurus), pig (Sus scrofa), sheep/goat (Ovis aries/Capra hircus) — and other wild game (Christenson 1989). Fish bones were also noted, but not identified. This pattern continues: excavation of a pre/early Gold Rush-era well/privy adjacent to Portsmouth Square in San Francisco's Chinatown resulted in one specimen identified as the locally available surfperch (Embiotocidae), along with goose and/or duck, cattle, and pig specimens (Valente 2012). Faunal remains from Gold Rush-era features in San Francisco's Mission District indicate that of the 1,124 skeletal elements recovered, cattle, sheep, and pig represent nearly 50\% of the identified assemblage (Pastron and Beevers 2003). The remaining specimens from these features include birds as well as unidentified mammalian and fish elements.

At Thompson's Cove (CA-SFR-186H), a Gold Rush archaeological site located near North Beach in San Francisco (Pastron and Bruner 2014), the faunal assemblage is represented by at least 50 species and more than 8,000 skeletal elements, but domesticates, including cattle, pig, sheep, and goat, dominate the assemblage (see tables 3, 14, and 17 in Conrad et al. 2015a). In Feature 7, which dates to the early 1850s, cattle, sheep and pigs represent $64 \%$ (number of identified specimens [NISP; Lyman 2008] = 826/1293) of the assemblage - a common trend for Gold Rush-era archaeological sites. Additional non-native species found throughout this site include a single chestnut cowrie shell (Cypraea spadicea), California margin shell (Volvarina taeniolata) - both of which were likely carried as tokens or gifts - two Galapagos tortoise humeri fragments, a green sea turtle phalanx, and several turkey (Meleagris gallopavo) elements. Diversity among the molluscs, birds, and fishes also provided important insights into Gold Rush diets at Thompson's Cove, but these organisms were largely limited to locally available species except for 18 cod vertebral elements previously identified to the genus Gadus (Table 3).

In particular, specimens from Thompson's Cove indicated exploitation of native fishes, including Sacramento pikeminnow (Ptychocheilus grandis) and Sacramento sucker (Castostomus occidentalis), from the inland freshwaters of California, providing further support that the consumption of fishes was not restricted to importation of exotic species from distant localities. Sturgeon (Acipenser sp.), salmon (Oncorhynchus sp./Oncorhynchus tshawytscha), and Pacific tomcod (Microgadus proximus) also occur at the site and were likely sourced from the San Francisco Bay itself.

A Gold Rush site in downtown Sacramento provides a second case for the presence of cod in northern California during the 1850s. At the Golden Eagle Hotel site, fish specimens recovered from three features dating to 1856 and 1866-1878 suggest exploitation of locally available fishes from inland freshwaters, the San Francisco Bay, and the California coast, and cod (not designated to species; Praetzellis et al. 1980; Schulz 1980, 1984; Table 2). Sacramento perch (Archoplites interruptus), thicktail chub (Gila crassicauda), steelhead, sturgeon, and other fishes were consumed at the Golden Eagle Hotel at that time, but the only fish which consistently appeared in all three features at the site was cod. The zooarchaeologist who made the cod identifications was unable to distinguish between Atlantic and Pacific cod but noted that either imported Atlantic cod or post-1863 imported Pacific cod may be present.

Appearance of archaeological cod bones in 1850s contexts in San Francisco and Sacramento strongly suggests the presence of imported Atlantic cod during this era based on historical documentation, but the presence of cod bones from 1860s-1870s contexts at the Golden Eagle Hotel may also indicate that Pacific cod was consumed during this era. This is also supported by additional later nineteenth-century zooarchaeological cod data from San Francisco, Stockton, San Jose, and Woodland, California (Gobalet 2006, 2014; Schulz 1984). For example, 
fish specimens recovered from two household contexts in downtown San Francisco, dating to the 1870s and 1880s, indicate the presence of rockfishes (Sebastes sp.), sand sole (Psettichthys melanostictus), sockeye salmon (Oncorhynchus nerka), and apparently, Pacific cod (St. Clair and Dobkin 2003; Table 2). However, these Pacific cod specimens were not analyzed using ancient DNA, and it is unclear which morphological features distinguished these Pacific cod specimens from Atlantic cod.

Further complicating inferences on historical cod import, and the zooarchaeological record of cod, is a striking 1853 newspaper record from Redding, California. The November 19, 1853, record notes, "Halibut, codfish, mackerel and Sardines are said to be abundant in the ocean, near the Northwest of our State. A vessel arrived at San Francisco a few days since from a fishing cruise, with seven hundred codfish" (Shasta Courier 1853f, emphasis added).

Comparison with San Francisco newspapers confirms this account — on November 8, 1853 (eight days prior), the schooner Queen of the West landed from a "fishing cruise" with 700 "fish" (Daily Alta California 1853e). This record cannot confirm that Pacific cod were fished and imported to San Francisco in 1853, but it is nonetheless significant. Although the bulk of Pacific cod fishing from San Francisco began in 1863, Pacific cod fishing may have begun 10 years earlier, during the Gold Rush.

Other newspaper accounts provide further support for this reinterpretation of the Pacific cod fishery record. On September 19, 1854 the Sacramento Daily Union, in an article titled "Pacific Fisheries," noted that cod and halibut are plentiful and sell in northern California markets at high prices while being "found farther . . . northward . . . in the neighborhood of Townsend Harbor, Port Orford, and off Vancoucer's [sic] and Queen Charlotte's Island." The Daily Alta California reported on September 22, 1855, that west-northwest of Cape Classet (Washington), "codfish can be caught in quantities" and that the cutter Jefferson Davis caught $300 \mathrm{cod}$ "at Seatles [sic]." This record also noted that "some of our enterprising Cape Codmen should bestir themselves, and take advantage of the opportunity thus offered of making a handsome business, as the fish are in the greatest abundance and can be easily taken" (Daily Alta California 1855). Finally, a May 14, 1857, article titled "Pacific Codfish" in the San Juaquin Republican noted:

It appears, at last, that Cape Cod is likely to have a rival in Steilacoom [Washington], and Puget sound. We have seen, says a San Francisco paper, some samples from the latter region, and tasted them also, in our market. The fish is not so large as the eastern, but exceedingly well cured and sweet. The supply of the raw material is said to be inexhaustible, and the cured fish can be afforded here at the reasonable price of three to four cents per pound.

Clearly, these records reinforce the need to reanalyze the Thompson's Cove cod to determine their species, and thus the route of import into the city during the Gold Rush.

\section{BACKGROUND AND METHODS}

Thompson's Cove

Cod at Thompson's Cove occurred in three features: 25 (NISP $=10$; minimum number of individuals $[\mathrm{MNI}$; Lyman 2008] $=1), 15(\mathrm{NISP}=2 ; \mathrm{MNI}=1)$, and $7(\mathrm{NISP}=6 ; \mathrm{MNI}=1$; Conrad et al. 2015a; Pastron and Bruner 2014; see the latter reference for site-specific feature information). These features all date to between the late 1840s and 1853. Gadus specimens from the site are solely vertebral elements: six complete caudal vertebrae, seven partial vertebrae, and 
five neural spines (Table 3). Kenneth W. Gobalet (KWG) based his identifications on the morphological differences in the vertebrae of G. macrocephalus and G. morhua in the osteological collection of the Ichthyology Department, California Academy of Sciences, Golden Gate Park, San Francisco.

Sediments from these three features were water-screened through $3.2 \mathrm{~mm}(1 / 8 \mathrm{inch})$ mesh in the laboratory and account for the majority (NISP=3,002/3,024 including scales) of all fish specimens recovered from the site (Conrad et al. 2015a). Feature 3/31/37 also received bulk sediment water-screening, but only a single fish bone was identified in this context and is not a cod. This is in sharp contrast to Feature 15, for example, which resulted in the identification of 575 fish bones and 1,385 scales using similar screening and laboratory processing. At Thompson's Cove this pattern is significant since all other features, as well as fish specimens, were either hand-collected during excavation or retrieved in $6.4 \mathrm{~mm}(1 / 4 \mathrm{inch})$ mesh in the field (note: cod at the Golden Eagle Hotel was recovered in both $3.2 \mathrm{~mm}$ and $6.4 \mathrm{~mm}$ mesh; Schulz 1980).

\section{Cod Processing and Taphonomy}

Based on historical records, following capture, the cod are taken to the mother ship or the shore, where they were bled, the head and viscera removed, and the anterior three-fifths of the vertebral column removed. This leaves caudal vertebrae in place when the salting process begins (Cobb 1916:56-57; Hittell 1882:343; Kurlansky 1997:103, 118; Mackovjak 2019:122-25; van

Klaveren and Legendre 1965). Therefore, given the historical record of importing Atlantic cod into California, the finding of only caudal vertebrae, or vertebral fragments, in the archaeological assemblage from Thompson's Cove is significant because it is consistent with these descriptions of cod processing (see additional discussions in Amundsen et al. 2005; Barrett 1997; Orton et al. 2014). One would anticipate finding caudal vertebrae at an archaeological site containing imported salted cod, and based on these descriptions, we anticipate that the cod remains found at Thompson's Cove are from Atlantic cod, even with historical references suggesting the possibility of early Pacific cod fishing during this time. Unfortunately, the lack of skeletal element descriptions for the cod from the Golden Eagle Hotel preclude us from determining if these remains represent specimens from dried, salted cod. Taphonomic analysis of the cod vertebrae and fragments from Thompson's Cove failed to identify any evidence of cut marks or other post-processing features (e.g., Schroth 1996).

\section{Ancient DNA}

Given the successful amplification of DNA in archaeological cod specimens (e.g., Star et al. 2017), in this analysis we selected five cod vertebrae from Thompson's Cove for ancient DNA (aDNA) analysis for species identification. These specimens are from Features $25(n=4)$ and 15 $(n=1)$. All pre-polymerase chain reaction (PCR) activities were conducted at the Laboratories of Molecular Anthropology and Microbiome Research (LMAMR; lmamr.org) at the University of Oklahoma. This facility is a dedicated workspace for processing aged, degraded, and/or LCN (low copy number) DNA samples. The lab takes precautions to minimize and monitor the introduction of contaminates.

DNA was extracted from 41.2 to $55.8 \mathrm{mg}$ subsamples of vertebrae removed from sample numbers $107,108,111,113$, and 870 . Each subsample was submerged in $6 \%(\mathrm{w} / \mathrm{v})$ sodium hypochlorite $(\mathrm{NaOCl})$ for 4 minutes, after which the $\mathrm{NaOCl}$ was poured off (Barta et al. 2013). The samples were submerged and rinsed with DNA-free water twice, then transferred to $1.5 \mathrm{~mL}$ tubes, with $500 \mathrm{~mL}$ of $0.5 \mathrm{M}$ ethylenediaminetetraacetic acid (EDTA) added to each of the tubes. The same volume of EDTA was added to a sixth $1.5 \mathrm{~mL}$ tube to serve as an extraction 
negative control. The set of six tubes was gently rocked at room temperature on a nutator for $>48$ hours.

DNA was then extracted following Kemp et al. (2014). First, $90 \mu$ of proteinase K were added to the samples and incubated at $65^{\circ} \mathrm{C}$ for 3 hours. Then the samples were centrifuged at $15,000 \mathrm{rpm}$ for 1 minute to pellet any remaining bone or dirt matter. The liquid was then transferred into new $2 \mathrm{~mL}$ tubes while avoiding co-transfer of the pelleted matter. Aliquots of $750 \mu \mathrm{l}$ of "resin" $(2.5 \%$ celite in $6 \mathrm{M}$ guanidine $\mathrm{HCl})$ and $250 \mu \mathrm{l}$ of $6 \mathrm{M}$ guanidine $\mathrm{HCl}$ were added to the tubes, which were then vortexed numerous times over a 3-minute period.

Promega Wizard® Minicolumns were attached to $3 \mathrm{~mL}$ luer-lok syringe barrels (with the plungers removed) and placed on a vacuum manifold. Three milliliters of DNA-free $\mathrm{ddH}_{2} \mathrm{O}$ was pulled across the columns, followed by the resin mixture. Then, $3 \mathrm{~mL}$ of $80 \%(\mathrm{v} / \mathrm{v})$ isopropanol was pulled across the columns to rinse the silica pelleted on the minicolumns. The columns were placed in $1.5 \mathrm{~mL}$ tubes and centrifuged at 10,000 rpm for 2 minutes to remove excess isopropanol. The columns were placed in new $1.5 \mathrm{~mL}$ tubes, and the old tubes discarded. Fifty microliters of $65^{\circ} \mathrm{C}$ DNA-free molecular water was added to the columns, followed by a waiting period of 3 minutes. Tubes were then centrifuged at 10,000 rpm for 30 seconds. An additional 50 $\mu \mathrm{l}$ of $65^{\circ} \mathrm{C}$ DNA-free molecular grade water was added to the tubes and centrifuged at 10,000 rpm for 30 seconds, following another 3-minute wait, resulting in $100 \mu$ of extracted DNA.

DNA extracts were tested for the presence of PCR inhibitors following Kemp et al. (2014) using ancient turkey DNA as a positive control (Kemp et al. 2017). Surprisingly, although the inhibition test indicated the five sample eluates to be "inhibited," they still amplified under normal PCR conditions, indicating that the extracts did not contain sufficient inhibitors to prevent successful amplification of the samples.

Primers were designed to amplify a 193 base pair (bp) region of the mitochondrial Cytochrome b gene, spanning nucleotide positions (nps) 14522 to 14714 relative to the Atlantic cod full mitochondrial DNA (mtDNA) reference sequence (GenBank accession: KX267089.1). The primer sequences are as follows: CodF 5'-AGACAGCCTTCTCATCCG-3' and CodR 5'ATTACTAAAAGGAAAAGGACAA-3'. The amplicons produced with these primers contain a 153 bp sequence that serves as a barcode to identify samples as either Atlantic cod or Pacific cod, with nine mutational differences consistently occurring between the two species.

PCRs were conducted with two different polymerases: Omni KlenTaq LA (DNA Polymerase Technology) and Platinum Taq (Invitrogen). In the case of the former, $15 \mu \mathrm{l}$ PCRs were prepared with $1 \times$ Omni KlenTaq Reaction Buffer (including a final concentration of 3.5 $\mathrm{mM} \mathrm{MgCl} 2$ ), $0.32 \mathrm{mM}$ dNTPs, $0.24 \mu \mathrm{M}$ of each primer, $0.3 \mathrm{U}$ of Omni KlenTaq LA polymerase, and $1.5 \mu \mathrm{l}$ of template DNA. PCR cycling conditions consisted of (1) a 3-minute hold at $94^{\circ} \mathrm{C}$; (2) 60 cycles of 15 -second holds at $94^{\circ} \mathrm{C}, 56^{\circ} \mathrm{C}$, and $68^{\circ} \mathrm{C}$; and (3) a 3-minute hold at $68^{\circ} \mathrm{C}$. Fifteen microliter PCRs were also prepared with $1 \times$ Platinum Taq Reaction Buffer, $0.32 \mathrm{mM}$ dNTPs, $1.5 \mathrm{mM} \mathrm{MgCl} 2,0.24 \mu \mathrm{M}$ of each primer, $1 \mathrm{U}$ of Platinum Taq, and $1.5 \mu \mathrm{l}$ of template DNA. PCR cycling conditions were (1) a 3-minute hold each at $94^{\circ} \mathrm{C}, 56^{\circ} \mathrm{C}$, and $72^{\circ} \mathrm{C}$; (2) 60 cycles of 15 -second holds at $94^{\circ} \mathrm{C}$; and (3) a 3-minute hold at $72^{\circ} \mathrm{C}$. PCRs were conducted with both full-concentration DNA eluates and their 1:10 dilutions. PCR negatives accompanied each batch of amplifications to monitor for potential contamination.

Two microliters of PCR product were separated on a $\%$ agarose gels, stained with GelRed, and viewed under ultraviolet light to confirm amplification. Amplicons were sequenced at the Biology Core Molecular Lab at the University of Oklahoma.

Under the above described conditions, results were obtained for all but one sample (870). 
This sample may have failed to amplify because it does not belong to the genus Gadus. To control for this possibility, we employed primers for generalized fish species identification using a $148 \mathrm{bp}$ sequence of the $12 \mathrm{~S}$ mitochondrial genome (Jordan et al. 2010). The reverse primer originally described by Jordan and colleagues was in the wrong orientation. Corrected here, the primers we used were: "OST12S-F" 5'-GCTTAAAACCCAAAGGACTTG-3' and "OST12S-R" 5'-CTACACCTCGACCTGACGTT-3'. Fifteen microliter PCRs were conducted as described above using Platinum Taq with an annealing temperature of $55^{\circ} \mathrm{C}$ for this primer set. Amplicons were sequenced at the Biology Core Molecular Lab at the University of Oklahoma.

\section{RESULTS}

Using comparative Pacific and Atlantic cod skeletons, KWG identified the cod vertebrae as Atlantic cod. In Pacific cod, there is a gap between the edge of the centrum and the base of the neural and hemal arches that is lacking in the Atlantic cod caudal vertebrae (Figure 3). These differences were corroborated by ancient DNA analysis.

All sequences were aligned to the Atlantic cod mitochondrial DNA reference sequence (GenBank accession: KX267089.1) with Sequencher v 5.4.6. Four of the five samples (107, 108, 111, and 113), all from Feature 25, were identified as Atlantic cod based on amplification with primers Cod F/R. Species identification was confirmed for each of these specimens from four amplifications each (Table 4). The fifth sample (870) from Feature 15 did not amplify with the $\mathrm{Cod} \mathrm{F} / \mathrm{R}$ primers and was identifiable only to the genus (Gadus) using primers OST12S-F/R. None of the extraction or PCR negatives revealed the presence of cod mtDNA. Furthermore, the sequences produced with the Cod F/R primers exclude samples 107, 108, 111, and 113 from being walleye pollock (Gadus chalcogrammus), which inhabits the North Pacific and is genetically distinct from both Atlantic and Pacific cod.

\section{DISCUSSION}

Identification of Atlantic cod in Gold Rush-era deposits from San Francisco supports the role of global maritime trade in 1850s northern California. Our study confirms the importing of Atlantic cod into San Francisco during this period but leaves several questions unanswered. Here, we focus on contextualizing the presence of Atlantic cod at Thompson's Cove within the (1) broader record of Pacific cod fisheries during the nineteenth century, (2) demand for food experienced during the Gold Rush, (3) transition between Atlantic cod importation and Pacific cod fishing during the 1860s and later, and (4) identification of cod in nineteenth-century California.

Based on current archaeological and ethnohistoric evidence, prior to the Gold Rush in 1848-1849, there was no commercial fishery of Pacific cod in California, although Alaska Natives, First Nations, and Native Americans fished cod for millennia prior to this period (see Butler and Campbell 2004; McKechnie and Moss 2016; Moss 2011). Recently, Tushingham and Christiansen (2015) noted the presence of unidentified "gadids" in far southern Oregon at the precontact midden of Tcetxo (35-CU-42), and in Humboldt Bay, in northern California, at the precontact village of Manila (CA-HUM-321), dating to between 1,300-1,500 and 1,800-2,000 years ago, respectively. This may suggest that while the bulk of precontact Pacific cod fishing occurred in the Pacific Northwest and in southeastern Alaska, Indigenous fishers also exploited gadids in northern California and southern Oregon, possibly by AD 700-but this inference is tenuous. For example, a major summary of the Native American fisheries in California identified no evidence for the exploitation of cod (Gobalet et al. 2004). Further identification and analysis of these gadid specimens is required to confirm their identification and provide insight into the exploitation and/or trade of these fish prior to the arrival of Spanish colonials, Russians, and Anglo-Americans into northern California. 
Based on evidence from late-precontact/early-contact fishing in the San Francisco Bay area, Native American communities caught and consumed a variety of fishes (Broughton 1997; Broughton et al. 2015; Gobalet 2020; Gobalet et al. 2004; Voss 2008). Many of these same fishes were exploited from the San Francisco Bay during the Spanish and Mexican periods preceding the Gold Rush (e.g., Voss 2008). Early-contact fishing has been documented at the Russian colony of Fort Ross (ca. 1812-1841) in Sonoma County, California (north of San Francisco), where Native Alaskan (Chugach and Kodiak Island Alutiiq) and Native Californian (Kashaya Pomo, Southern Pomo, and Coastal Miwok) peoples lived together but used different techniques (hook and line vs. intertidal capture, by hand), and none exploited cod (Gobalet 1997; Lightfoot et al. 1997). Since cod inhabit deep-water habitats off the California coast (Love 2011), the limited or nonexistent demand for Pacific cod prior to and during the Gold Rush may be a result of the inaccessibility of Pacific cod.

Pacific cod are found several hundred feet below the surface in marine waters off California and were presumably difficult to fish and access by Native peoples and later colonists. Gold Rush-era descriptions of wild game often cite the delicious, large, and abundant local fishes, but cod were never mentioned as a local product (Bancroft 1888:191; Davis 1889:227; Soulé et al. 1854:146, 148, 360, 546-47; Taylor 1868:222). The single 1853 newspaper record indicating fishing of Pacific cod off the northwest coast of California identified in this study (Shasta Courier 1853f) is intriguing and may indicate small-scale, market-level cod fishing during the Gold Rush, but it is not currently supported by zooarchaeological records. For example, several 1850s newspapers indicate the presence of schooner-based fishing cruises which returned large catches to San Francisco. On January 29, 1852, the Mount Vernon landed from a "fishing cruise" with 600 fish; the Orleans landed 300 fish on May 7, 1852; the J.W. Brown landed 1,000 fish from Catalina Island (Channel Islands) on January 24, 1853; the Odd Fellow landed 1,100 fish from Drake's Bay (Marin County, California) and the J.W. Brown landed 800 fish, both on February 8, 1853; and the Bay State landed 1,000 fish on May 27, 1853 (Daily Alta California 1852a, 1852b, 1853a, 1853b, 1853d). These records are not exhaustive, nor do they indicate specific fishes caught and landed. Instead, they suggest that the Gold Rush populace fished, in some instances, for Pacific cod.

In general, the large-scale Pacific cod fishery developed in the early 1860s (Mackovjak 2019; Scofield 1954). Traditionally, the earliest cited record of a Pacific cod catch entering San Francisco occurred in 1863. When this Pacific cod fishery began, schooners sailed to Alaska and the coast of Russia to catch Pacific cod where the fish were cleaned and salted aboard vessels, then returned to the San Francisco Bay area for repacking and/or consumption (Clemens and Wilby 1961; Cobb 1916; Collins 1892; Hart 1973; Love 2011; Mackovjak 2019; Scofield 1954). Therefore, the identification of Atlantic cod within 1850s Gold Rush deposits in San Francisco, and possibly Sacramento based on Gadus bones dating to 1856, is significant. Why are nonnative cod present in this archaeological record when, presumably, there was an abundance of native fish available to the local population? This is a complex question involving aspects of colonization, Gold Rush prejudice, lack of traditional knowledge (or engagement), and more. For the purposes of our study, the basic demand for food during the Gold Rush, and the influence and connectivity of San Francisco to global maritime trade economies, helps explain this evidence.

During the early Gold Rush, historical accounts describe a tumultuous period of activity. A pattern that appears in many of these records is the enormous demand for food that began in 1849 and continued for several years, until approximately 1853 (Bancroft 1888; Davis 1889; 
Soulé et al. 1854; Taylor 1868). So many gold-seekers arrived in 1849 that San Francisco's domestic and newly established import food markets became heavily lopsided, with enormous demand but little supply, especially in domesticated plants and animals. A wild game market quickly emerged, and it included native fishes (Stine 1980), but this supply did not resolve widespread food scarcity. Entrepreneurial gold miners and merchants within and outside of California devised several solutions to answer the demand for food, including importation of foodstuffs from markets both near and far from San Francisco - an easily established trade given San Francisco's influence on global maritime trade (Delgado 2009). For example, native Pacific oysters (Ostrea lurida), which were quickly overexploited in the San Francisco Bay area, were subsequently imported from far northern California, Oregon, and Washington (Conrad et al. 2015b). Imports also included massive quantities of marine bird eggs from the Farallon Islands (Ainley and Lewis 1974; Doughty 1971), exotic Galapagos tortoises (Conrad and Pastron 2014; Conrad et al. 2015a), green sea turtles (Conrad et al. 2018), and in some cases, "green peas, halibut, green corn, [and] codfish" (Daily Alta California 1850a, emphasis added). Beginning as early as 1848-1849, San Francisco newspaper records document the import of cod (see Table 1). Simmons, Hutchinson \& Co. advertised "2,000 lbs cod fish" on September 6, 1849, while the vessel Columbia advertised " 50 boxes of dried cod fish" on December 10, 1850; "50,000 pounds in drums" was for sale at Bradshaw \& Co. on May 25, 1853 (Figure 4), and "40 drums [of] codfish" was for sale at Arrington \& Co. on March 12, 1854 (Daily Alta California 1849, 1850d, $1853 \mathrm{c}, 1854)$.

Since long-term ice storage and refrigeration was not available on maritime vessels during the Gold Rush era, it is not surprising that historical accounts describe the import of "dried" cod or "drums" of cod. By the 1850s, New England fisheries in the United States nearly perfected the craft of catching, drying, and salting Atlantic cod (Figure 2; Kurlansky 1997). In fact, New England mariners, commonly the captains and crews of vessels transporting individuals to the goldfields, found salted cod to be delectable, often in stark contrast to the opinion held by their passengers. A passenger traveling on the bark Canton en route to San Francisco in 1849 wrote, "While writing this the Steward has just passed me with a tubful of this filthy and rotten codfish, which some of the beauties [crew] prefer and call a treat!" (Lewis 1949:109-10). A similar grievance was written by Samuel Upham while traveling to San Francisco on the brig Osceola in 1849. Discussing the captain's treatment of the steerage passengers during meals, he wrote, "He is a sea-tyrant, and totally unfit to command a passenger vessel. The dinner for the steerage passengers to-day consisted of boiled codfish and hard tackall told!" (emphasis in original; Upham 1878:48).

This evidence suggests that the cod imported to San Francisco during the Gold Rush, and ultimately deposited at Thompson's Cove, and likely the Golden Eagle Hotel in Sacramento, resulted from shipping salted Atlantic cod to northern California, possibly from New England (see also Collins 1892). Regardless of the consumer's taste or desire, codfish clearly represented a foodstuffs necessity during this time. Genetic and morphological identification of Atlantic cod in this study, the historical record of food shortages, import of foodstuffs, connection of San Francisco to global maritime markets (Delgado 2009), the North Atlantic cod fishery (Kurlansky 1997), and the presence of Atlantic cod caudal vertebrae at Thompson's Cove (Table 3) - a common signature of dried, salted cod - all support this argument.

Confirmation of Atlantic cod being deposited in 1850s San Francisco helps contextualize the role and demand of food in facilitating San Francisco's influence on global maritime markets during this era, but it leaves significant questions unanswered. Once the Pacific cod fishery 
began in 1863, did the importation of Atlantic cod end? If not, how were Pacific and Atlantic cod viewed and consumed within socioeconomic markets in northern California? And, how does this record influence - or how is it influenced by_zooarchaeological cod data from the later nineteenth century (e.g., identifying cod based on their temporal affiliation)? Although these questions require additional research, a cursory examination of later nineteenth-century zooarchaeological and historical records is suggestive: Atlantic cod continued to be imported alongside Pacific cod, but these species become differentiated in local markets.

On September 18, 1863, Captain Mathew Turner arrived in San Francisco with 15 tons of Pacific codfish, fished from the Gulf of Tartary, Alaska (Daily Alta California 1863b, 1863c). This radically altered the cod market in San Francisco and the greater Pacific (Mackovjak 2019) by facilitating the import of massive quantities of cod into the city and the creation of an export market for codfish from San Francisco to global markets. As the Daily Alta California (1853c) wrote of Turner's arrival:

A part of her cargo is a new importation for California, being nothing less than fifteen tons of codfish. ... They are somewhat smaller than the Newfoundland codfish, but resemble those taken on the coast of Labrador, and are in every respect equal to the best found in Atlantic waters.

Yet, even prior to this event, codfish in San Francisco appear to be differentiated in markets based on their origin - something that did not occur during the Gold Rush. For example, on March 13, 1863, an advertisement for the salesroom of Jones \& Bendixen indicated that "15 drums Isthmus Codfish" were for sale (Daily Alta California 1863a). The cargo of the Electra direct from Hamburg, on July 26, 1870, also included numerous cases of "desiccated codfish," a term not previously associated with cod in local markets, and presumably indicating Atlantic cod (Daily Alta California 1870). S.L. Jones \& Co. (a continuation of Jones \& Bendixen) also advertised "15 drums Eastern Codfish" on October 24, 1871 (Daily Alta California 1871). These records suggest the establishment of distinct codfish markets, and an advertisement from April 3, 1868 highlights this well (Figure 5). In this advertisement, "eastern" and "Pacific" codfish were sold together, but identified separately for consumers; this occurred after the Gold Rush ended and during the era of large-scale Pacific cod fishing.

Zooarchaeological records from northern California also appear to support this historical record (Figure 6). While this sample is small and is not exhaustive-representing only ten distinct archaeological deposits - it suggests that Pacific cod enter the zooarchaeological record during the $1870 \mathrm{~s}$, but this record lacks critical confirmation from aDNA analysis. The only confirmed Atlantic cod thus far occurs at Thompson's Cove during the Gold Rush, but multiple sites exhibit cod bones with unclear speciation (i.e., Gadus and gadidae). These data on cod bones do not distinguish between Atlantic and Pacific cod, but they are nonetheless important. For example, the skeletal elemental representation of 22 cod bones from San Francisco sites dating to between 1870 and 1899 is clearly suggestive of Pacific cod exploitation based on the wide diversity of elements present (William Self and Associates 2019): caudal vertebrae (NISP = $12)$, cleithra (NISP $=3)$, supracleithra $(\mathrm{NISP}=2)$, basioccipital $(\mathrm{NISP}=1)$, quadrate $(\mathrm{NISP}=1)$, branchiostegal rays (NISP $=2$ ), and unidentified vertebra (NISP $=1)$. Because these are cranial and pectoral elements, they could not have been prepared as described above for preserved Atlantic cod; instead, they were likely from freshly caught cod, stored on ice and shipped from 
Alaska to California (see also discussions in Amundsen et al. 2005; Barrett 1997; Orton et al. 2014).

It is intriguing to note that codfish appear in zooarchaeological collections far distant from northern California, suggesting multiple avenues of cod import and transportation during the nineteenth and early twentieth centuries. For example, research at a central Nevada mining community dating to the late nineteenth/early twentieth centuries identified a single Atlantic cod bone in an American Chinese occupation context, and 14 Atlantic cod bones from a Euroamerican restaurant context (Simons 1999). Excavations at a late-nineteenth/earlytwentieth-century residence in north-central Nevada also identified a single Gadus sp. bone (Wiley and Ross-Hauer 2017). Archaeological investigations recovered six Gadus vertebrae from similar dated contexts in Tucson, Arizona (KWG, personal communication).

Finally, while we identified a morphological approach for distinguishing Atlantic and Pacific cod in zooarchaeological assemblages from nineteenth-century California, studies of fish collections from this era clearly require use of aDNA and more thorough development and examination of Gadus sp. comparative morphology for identification purposes. This approach would broadly benefit cod identification, as well as that of other fishes - for example, the possible presence of sockeye salmon in 1870s-1880s San Francisco (see Table 2). It would also provide insights into past species diversity for the now extinct thicktail chub from 1860s-1870s Sacramento (see Table 2). Future studies should focus on rigorously examining Atlantic and Pacific cod morphology and applying aDNA analyses to confirm species presence or absence in archaeological sites. The 87 elements reported as G. microcephalus from 1870s-1880s San Francisco (Table 2) should be reexamined with aDNA to confirm their origin. Future work is especially relevant since Pacific cod likely entered Gold Rush-era diets, in small quantities, as early as 1853. As this research occurs in northern California and elsewhere in the American West, exploring the relationship between Atlantic cod importation, the Pacific cod fishery, northern California fish markets, consumerism, and epicureanism will prove fruitful for clarifying this record.

\section{CONCLUSIONS}

San Francisco was undoubtedly an exhilarating and exhausting place to inhabit during the Gold Rush. Notably, rampant fires would destroy the city, rain and mud would consume entire horsedrawn carts, thousands of dollars' worth of gold dust would be gambled multiple times each night, there was an overabundance of guns and alcohol, and a continual search for shelter and food (Bancroft 1888; Soulé et al. 1854). Demand for food led to the importation of a variety of plant and animal products. Some of these faunas included oysters, marine-bird eggs, kangaroos, Galapagos tortoises, green sea turtles, and now, based on traditional morphological analysis, ancient DNA evidence, and insights from the historical record, Atlantic cod. Our research indicates that Atlantic cod was imported to San Francisco, likely dried and salted, during the Gold Rush era. We believe this is the earliest established physical record of Atlantic cod importation into the San Francisco Bay area, but it is surely not the only or the last. Although large-scale Pacific cod fisheries began in the 1860s when vessels traveled to Alaska for their catch, at least several records suggest that small-scale fishing operations were already exploiting Pacific cod stocks as early as 1853 . These records provide new, significant insight into the global record of animal exploitation, human migration, and cod trade during the mid-nineteenth century in San Francisco. 
We are extremely grateful to Emily Lena Jones for her support of this research project. We thank Laura Kelly and Vince Buonaccorsi for providing preliminary aDNA results, and Milton Love for facilitating their early aDNA research. We are also thankful to Ryan Kennedy and James Mackovjak for providing early reviews of this manuscript. Thanks also to Cara Monroe for assistance in the laboratory, Gabriel Sanchez for provided specimens of Pacific cod for morphological identifications, and Allison Vanderslice, Kari Lentz, Madeline Ware Van der Voort, Mary Praetzellis, and Adrian Praetzellis for providing references. The authors declare no competing interests. All errors or omissions in the text are our own, and all data included in this research are described and provided in text. See GenBank for reference sequences. Funding for the excavations at Thompson's Cove occurred through a cultural resources contract required for development work under California state law for the investigation and examination of historic properties at this location (funded by the development company). We obtained no additional outside funding for this research. No permits were obtained or required for this research as our samples derive from privately owned and developed property in San Francisco, California. Finally, thank you for substantive and beneficial comments and revisions provided by three anonymous reviewers and the journal editor, Lawrence Straus.

1. Newspaper articles were accessed online from the California Digital Newspaper Collection (CDNC), Center for Bibliographic Studies and Research, University of California, Riverside. The collection can be searched at http://cdnc.ucr.edu.

\section{REFERENCES CITED}

Ainley, David G., and T. James Lewis. 1974. The history of Farallon Island marine bird populations: 1854-1972. The Condor 76(4):432-46.

Ambro, Richard D. 2003. They danced in the plaza: The historical archaeology of Notre Dame Plaza, Mission San Francisco de Asis (Dolores), 347 Dolores Street, San Francisco, California. Report to Mercy/Charities Housing California, San Francisco, from Holman and Associates, San Francisco, CA. Available from the Northwest Information Center, California Historical Resources Information System, Rohnert Park, CA.

Amundsen, Colin, Sophia Perdikaris, Thomas H. McGovern, Yekaterina Krivogorskaya, Matthew Brown, Konrad Smiarowski, Shaye Storm, Salena Modugno, Malgorzata Frik and Monica Koczela. 2005. Fishing booths and fishing strategies in medieval Iceland: An archaeofauna from the site of Akurvik, North-West Iceland. Environmental Archaeology 10(2):127-42.

Bancroft, Hubert H. 1888. The history of California, Vol. VI: 1848-1859. San Francisco: History Company.

Barrett, James H. 1997. Fish trade in Norse Orkney and Caithness: A zooarchaeological approach. Antiquity 71:616-38.

Barta, Jodi Lynn, Cara Monroe, and Brian M. Kemp. 2013. Further evaluation of the efficacy of contamination removal from bone surfaces. Forensic Science International 231(13):340-48.

Broughton, Jack M. 1997. Widening diet breadth, declining foraging efficiency, and prehistoric harvest pressure: Ichthyofaunal evidence from the Emeryville Shellmound, California. Antiquity 71(274):845-62.

Broughton, Jack M., Erik P. Martin, Brian McEneaney, Thomas Wake and Dwight D. Simons. 2015. Late Holocene anthropogenic depression of sturgeon in San Francisco Bay, 
California. Journal of California and Great Basin Anthropology 35(1):3-27.

Butler, Virginia L., and Sarah K. Campbell. 2004. Resource intensification and resource depression in the Pacific Northwest of North America: A zooarchaeological review. Journal of World Prehistory 18(4):327-405.

Californian, The (Salinas). 1848. “Bee hive.” Vol. 2, No. 37, January 26, 1848. Accessed online from http://cdnc.ucr.edu.

Christenson, Lynne E. 1989. "A study of some subsistence practices in 1851 San Francisco," in Archaeological investigations at an 1851 commercial site along Howison's Pier, San Francisco, California: 343 Sansome Street, pp. 1-29. Prepared by Dames \& Moore for the City and County of San Francisco, Department of Planning. Available from the Northwest Information Center, California Historical Resources Information System, Rohnert Park, CA.

Clemens, Wilbert Amie, and G. V. Wilby. 1961. Fishes of the Pacific Coast of Canada. Ottawa: Fisheries Research Board of Canada.

Cobb, J. N. 1916. Pacific cod fisheries. Bureau of Fisheries Document No. 830. Washington, DC.

Collins, J. W. 1892. Report on the fisheries of the Pacific Coast of the United States. Report of the Commissioner for 1888. Washington, DC: U.S. Commission of Fish and Fisheries.

Conrad, Cyler. 2017. Kangaroos and the California Gold Rush. California History 94(3):62-65.

Conrad, Cyler, and Allen Pastron. 2014. Galapagos tortoises and sea turtles in Gold Rush-era California. California History 91(2):20-39.

Conrad, Cyler, Kenneth W. Gobalet, Kale Bruner, and Allen G. Pastron. 2015a. Hide, tallow and terrapin: Gold Rush-era zooarchaeology at Thompson's Cove (CA-SFR-186H), San Francisco, California. International Journal of Historical Archaeology 19:502-51.

Conrad, Cyler, Kale Bruner, and Allen G. Pastron. 2015b. Anthropogenic contamination in Gold Rush-era Native Pacific oysters (Ostrea lurida Carpenter 1864) from Thompson's Cove (CA-SFR-186H), San Francisco, California. Journal of Archaeological Science: Reports 3:188-93.

Conrad, Cyler, Laura Pagès Barceló, Jeffrey A. Seminoff, Calandra Turner Tomaszewicz, Marie Labonte, Brian M. Kemp, Emily Lena Jones, Michael Stoyka, Kale Bruner, and Allen Pastron. 2018. Ancient DNA analysis and stable isotope ecology of sea turtles (Cheloniidae) from the Gold Rush-era (1850s) Eastern Pacific Ocean. Open Quaternary 4(3). http://doi.org/10.5334/oq.41

Crosby \& Dibblee. 1855. Company correspondence. California State Library. Accessed Fall 2020 from the Online Archive of California (https://oac.cdlib.org/).

Daily Alta California (San Francisco). 1849. "Simmons, Hutchinson \& Co." Vol. 1, No. 36, September 6, 1849. Accessed online from http://cdnc.ucr.edu.

1850a. "Cargo of ship Carthage." Vol. 1, No. 44, February 19, 1850. Accessed online from http://cdnc.ucr.edu.

1850b. "Importations." Vol. 1, No. 230, September 18, 1850. Accessed online from http://cdnc.ucr.edu. 1850c. "Importations." Vol. 1, No. 296, November 24, 1850. Accessed online from http://cdnc.ucr.edu.

1850d. "Cargo of the ship Columbia." Vol. 2, No. 1, December 10, 1850. Accessed online from http://cdnc.ucr.edu. 
- 1850e. "Importations." Vol. 2, No. 2, December 11, 1850. Accessed online from http://cdnc.ucr.edu.

—. 1850f. "Importations.” Vol. 2, No. 3, December 12, 1850. Accessed online from http://cdnc.ucr.edu.

—. 1850g. "Importations." Vol. 2, No. 4, December 13, 1850. Accessed online from http://cdnc.ucr.edu.

_. 1850h. "Importations." Vol. 2, No. 6, December 15, 1850. Accessed online from http://cdnc.ucr.edu.

—. 1850i. "Importations." Vol. 2, No. 14, December 23, 1850. Accessed online from http://cdnc.ucr.edu.

—. 1851a. "Importations." Vol. 2, No. 29, January 8, 1851. Accessed online from http://cdnc.ucr.edu.

—. 1851b. "Importations." Vol. 2, No. 48, January 27, 1851. Accessed online from http://cdnc.ucr.edu.

—. 1852a. "Shipping intelligence." Vol. 3, No. 28, January 29, 1852. Accessed online from http://cdnc.ucr.edu.

- 1852b. "Shipping intelligence." Vol. 3, No. 66, March 7, 1852b. Accessed online from http://cdnc.ucr.edu.

—. 1853a. "Shipping intelligence." Vol. 4, No. 24, January 24, 1853. Accessed online from http://cdnc.ucr.edu.

—. 1853b. "Shipping intelligence." Vol. 4, No. 38, February 8, 1853. Accessed online from http://cdnc.ucr.edu.

. 1853c. "Bradshaw \& Co.” Vol. 4, No. 144, May 25, 1853. Accessed online from http://cdnc.ucr.edu.

. 1853d. "Shipping intelligence." Vol. 4, No. 146, May 27, 1853. Accessed online from http://cdnc.ucr.edu.

—. 1853e. "Shipping intelligence." Vol. 4, No. 290, November 8, 1853. Accessed online from http://cdnc.ucr.edu.

—. 1854. “40,000 lbs. green Rio coffee.” Vol. 5, No. 70, March 12, 1854. Accessed online from http://cdnc.ucr.edu.

- 1855. "Halibut and cod fisheries." Vol. 6, No. 234, September 22, 1855. Accessed online from http://cdnc.ucr.edu.

—. 1863a. "Auction sales.” Vol. 15, No. 4766, March 13, 1863. Accessed online from http://cdnc.ucr.edu.

—. 1863b. "Importations." Vol. 15, No. 4952, September 18, 1863. Accessed online from http://cdnc.ucr.edu.

—. 1863c. "Fish from the Gulf of Tartary." Vol. 15, No. 4953, September 19, 1863. Accessed online from http://cdnc.ucr.edu.

—. 1868. “Codfish! Codfish!” Vol. 20, No. 6593, April 3, 1868. Accessed online from http://cdnc.ucr.edu.

—. 1870. “Auction sales.” Vol. 22, No. 7431, July 26, 1870. Accessed online from http://cdnc.ucr.edu.

—. 1871. "Auction sales." Vol. 23, No. 7883, October 24, 1871. Accessed online from http://cdnc.ucr.edu.

Davis, William Heath. 1889. Sixty years in California. San Francisco: A.J. Leary.

Delgado, James P. 1996. To California by sea: A maritime history of the California Gold Rush. 
Columbia: University of South Carolina Press.

- 2009. Gold Rush port: The maritime archaeology of San Francisco's waterfront. Berkeley: University of California Press.

Doughty, Robin W. 1971. San Francisco's nineteenth-century egg basket: The Farallons. Geographical Review 61(4):554-72.

Gobalet, Kenneth W. 1997. "Fish remains from the early $19^{\text {th }}$ century Native Alaskan habitation at Fort Ross," in The Native Alaskan neighborhood: A multiethnic community at Colony Ross. The archaeology and ethnohistory of Fort Ross, California, Vol. 2, pp. 319-27. Berkeley: Contributions of the University of California Archaeological Research Facility. - 2006. Fish Remains from "Valencia Gardens," a late $19^{\text {th }}$ Century Farm in the Mission District of San Francisco, California. Report submitted to Archeo-Tec. Available from the Northwest Information Center, Center for Historical Resources Information System, Rohnert Park, CA. . 2014. San Jose privy fish analysis. Report submitted to Holman and Associates. Available from the Northwest Information Center, California Historical Resources Information System, Rohnert Park, CA. . 2020. "Fish remains from archaeological site CA-ALA-565/H and a summary of the fishes in the archaeological record of the San Francisco Bay," in Protohistoric village organization and territorial maintenance: The archaeology of Sii Tuupentak (CA-ALA565/H) in the San Francisco Bay area, pp. 230-236. Davis: Center for Archaeological Research.

Gobalet, Kenneth W., Peter D. Schulz, Thomas A. Wake, and Nelson Siefkin. 2004. Archaeological perspectives on Native American fisheries of California, with emphasis on steelhead and salmon. Transactions of the American Fisheries Society 133(4):801833.

Hart, John L. 1973. Pacific fishes of Canada. Ottawa: Fisheries Research Board of Canada. Hattori, Eugene M., and Jerre L. Kosta. 1990. "Packed pork and other foodstuffs from the California Gold Rush," in The Hoff Store site and Gold Rush merchandise from San Francisco, California. Edited by Allen G. Pastron and Eugene M. Hattori, pp. 82-93. Ann Arbor: Society for Historical Archaeology.

Hittell, John S. 1882. The commerce and industries of the Pacific Coast of North America. San Francisco: A. L. Bancroft \& Co.

Holliday, J. S. 1981. The world rushed in: The California Gold Rush experience. New York: Simon and Schuster.

Johnston, K. M. 1964. San Francisco as it is: Being gleanings from the picayune, 1850-1852. Georgetown: Talisman Press.

Jordan, Leah G., Craig A. Steele, and Gary H. Thorgaard. 2010. Universal mtDNA primers for species identification of degraded bony fish samples. Molecular Ecology Resources 10(1):225-28.

Kemp, Brian M., Cara Monroe, Kathleen G. Judd, Erin Reams, and Colin Grier. 2014. Evaluation of methods that subdue the effects of polymerase chain reaction inhibitors in the study of ancient and degraded DNA. Journal of Archaeological Science 42:373-80.

Kemp, Brian M., Kathleen Judd, Cara Monroe, Jelmer W. Eerkens, Lindsay Hilldorfer, Connor Cordray, Rebecca Schad, Erin Reams, Scott G. Ortman, and Timothy A. Kohler. 2017. Prehistoric mitochondrial DNA of domesticate animals supports a 13th century exodus from the northern US Southwest. PLoS One 12:e0178882. 
Kurlansky, Mark. 1997. Cod: A biography of the fish that changed the world. New York: Penguin Books.

Lewis, Oscar. 1949. Sea routes to the gold fields: The migration by water to California in 18491852. New York: Alfred A. Knopf.

Lightfoot, Kent G., Ann M. Schiff and Thomas A. Wake. 1997. "Conclusion," in The Native Alaskan neighborhood: A multiethnic community at Colony Ross. The archaeology and ethnohistory of Fort Ross, California, Vol. 2, pp. 420-429. Berkeley: Contributions of the University of California Archaeological Research Facility.

Lotchin, Roger W. 1974. San Francisco, 1846-1856: From hamlet to city. Urbana and Chicago: University of Illinois Press.

Love, Milton. 2011. Certainly more than you want to know about the fishes of the Pacific Coast. Santa Barbara: Really Big Press.

Lyman, R. Lee. 2008. Quantitative paleozoology. Cambridge: Cambridge University Press.

Mackovjak, James. 2019. Alaska codfish chronicle: A history of the Pacific cod fishery in Alaska. Fairbanks: University of Alaska Press.

McKechnie, Ian, and Madonna L. Moss. 2016. Meta-analysis in zooarchaeology expands perspectives on Indigenous fisheries of the Northwest Coast of North America. Journal of Archaeological Science: Reports 8:470-85.

Moss, Madonna L. 2011. "Pacific cod in southeast Alaska: The "cousin" of the fish that changed the world," in The archaeology of North Pacific fisheries. Edited by Madonna L. Moss and Aubrey Cannon, pp. 149-170. Fairbanks: University of Alaska Press.

Orton, David C., James Morris, Alison Locker and James H. Barrett. 2014. Fish for the city: meta-analysis of archaeological cod remains and the growth of London's northern trade. Antiquity 88:516-30.

Pastron, Allen G., and L. Dale Beevers. 2003. On the Edge of Gold Mountain: The Archaeology of the Wing Lee Laundry Site. Prepared by Archeo-Tec, Inc., for the San Francisco Redevelopment Agency. Available from the Northwest Information Center, California Historical Resources Information System, Rohnert Park, CA.

Pastron, Allen G., and Kale Bruner. 2014. Final Archaeological Resources Report for the 717 Battery Street Project, City and County of San Francisco, California. Prepared by Archeo-Tec, Inc., for Northwest Realty Advisors. Available from the Northwest Information Center, California Historical Resources Information System, Rohnert Park, CA.

Pomfret, John Edwin. 1954. California Gold Rush Voyages, 1848-1849: Three Original Narratives. Los Angeles: The Huntington Library.

Praetzellis, Mary. 2015. Final Archaeological Resources Report and Data Recovery Report for the Privy 1 Collection, 355-399 Fremont Street, San Francisco, California. Prepared by the Anthropological Studies Center. Available from the Northwest Information Center, California Historical Resources Information System, Rohnert Park, CA.

- 2017. Final archaeological resources report and data recovery report for 110 The Embarcadero, San Francisco, California. Prepared by the Anthropological Studies Center for the Commonwealth Club of California. Available from the Northwest Information Center, California Historical Resources Information System, Rohnert Park, CA.

Praetzellis, Mary, Adrian Praetzellis, and Marley R. Brown III, eds. 1980. Historical archaeology at the Golden Eagle Site. Cultural Resources Facility, Anthropological 
Studies Center, Sonoma State University, for the Redevelopment Agency of the City of Sacramento. Available from the Northwest Information Center, California Historical Resources Information System, Rohnert Park, CA.

Sacramento Daily Union. 1854. "Pacific fisheries.” Vol. 8, No. 1089, September 19, 1854. Accessed online from http://cdnc.ucr.edu.

San Joaquin Republican. 1857. "Pacific codfish." Vol. 7, No. 114, May 14, 1857. Accessed online from http://cdnc.ucr.edu.

Schroth, Adella B. 1996. An ethnographic review of grinding, pounding, pulverizing, and smoothing with stones. Pacific Coast Archaeological Society Quarterly 32(4):55-75.

Schulz, Peter D. 1980. "Fish remains," in Historical archaeology at the Golden Eagle Site. Edited by Mary Praetzellis, Adrian Praetzellis, and Marley R. Brown III, pp. 2.1-2.18. Available from the Northwest Information Center, California Historical Resources Information System, Rohnert Park, CA.

1984. "Nineteenth-century fish remains from Woodland, California," in The Chinese Laundry on Second Street. California Archaeological Reports 24:158-66. California Department of Parks and Recreation, Sacramento.

Scofield, W. L. 1954. California fishing ports. Marine Fisheries Branch, Fish Bulletin No. 96. California Department of Fish and Game, Sacramento.

Shasta Courier (Redding). 1853f. "Halibut, codfish, mackerel ..." Vol. 2, No. 37, November 19, 1853. Accessed online from http://cdnc.ucr.edu.

Simons, Dwight D. 1999. Bullion and beefsteak, miners and mutton, headframes and hog meat, a chicken in every pot and fish on Fridays too! The zooarchaeology of Ruby Hill, Eureka County, Nevada. Nevada Archaeologist 17:29-41.

Soulé, Frank, John H. Gihon, and James Nisbet. 1854. The annals of San Francisco. New York: D. Appleton.

St. Clair, Michelle C., and Marjorie Dobkin. 2003. Report on technical and interpretive studies for historical archaeology: Central Freeway Replacement Project (Q4-SF-101 post miles 4.7/5.1/EA 291002) in the city of San Francisco, San Francisco County, California. Prepared by the URS Corporation for the Department of Public Works, City and County of San Francisco. Available from the Northwest Information Center, California Historical Resources Information System, Rohnert Park, CA.

Star, Bastiaan, Sanne Boessenkool, Agata T. Gondek, Elena A. Nikulina, Anne Karin Hufthammer, Christophe Pampoulie, Halvor Knutsen, Carl André, Heidi M. Nistelberge, Jan Dierking, Christoph Petereit, Dirk Heinrich, Kjetill S. Jakobsen, Nils Chr. Stenseth, Sissel Jentoft, and James H. Barrett. 2017. Ancient DNA reveals the Arctic origin of Viking Age cod from Haithabu, Germany. Proceedings of the National Academy of Sciences (USA) 114(34):9152-57.

Stine, Scott William. 1980. Hunting and the faunal landscape: Subsistence and commercial venery in early California. M.A. thesis, University of California, Berkeley.

Taylor, Bayard. 1868. El Dorado. New York: G.P. Putnam and Son.

Tushingham, Shannon, and Colin Christiansen. 2015. Native American fisheries of the northwestern California and southwestern Oregon coast: A synthesis of fish-bone data and implications for Late Holocene storage and socio-economic organization. Journal of California and Great Basin Anthropology 35(2):189-215.

Upham, Samuel C. 1878. Notes of a voyage to California via Cape Horn, together with scenes in El Dorado in the years 1849-'50. Philadelphia: Published by the Author. 
Valente, Nancy. 2012. "The vertebrate faunal remains from the Chinatown/North Beach Campus Project, Feature 2, San Francisco, California," in City College of San Francisco Chinatown/North Beach Campus, San Francisco, California: Archaeological monitoring report, pp. 99-111. Available from the Northwest Information Center, California Historical Resources Information System, Rohnert Park, CA.

van Klaveren, F.W., and R. Legendre. 1965. "Salted cod," in Fish as food. Edited by Georg Borgstrom, vol. III: Processing, part 1, pp. 133-63. London: Academic Press.

Voss, Barbara L. 2008. The archaeology of ethnogenesis: Race and sexuality in colonial San Francisco. Berkeley: University of California Press.

Waterman, J. J. 1969. Measures, stowage rates and yields of fishery products. Torry Advisory Note No. 17. Aberdeen: Torry Research Station.

Wiley, Ashley Konoske, and JoEllen Ross-Hauer. 2017 “26LA4340 (CrNV-62-6610)," in Mitigation of the Cortez Hills Expansion Project, pp. 705-850. Prepared by the Summit Envirosolutions, Inc. Available from the Battle Mountain District, Bureau of Land Management, Nevada.

William Self Associates, Inc. 2013. Transbay Transit Center Program Addendum to the Final Archaeological Research Design and Treatment Plan for the Existing Transbay Transit Terminal and Ramp Demolition, Utility Relocation, and New Transit Center Foundation Excavation (DURF), Addressing Block 6 of the Transbay Redevelopment Project Area. Available from the Northwest Information Center, California Historical Resources Information System, Rohnert Park, CA. . 2019. Transbay Program: Final Archaeological Resources Report for the Existing Transbay Transit Terminal and Ramp Demolition, Utility Relocation, and New Transit Center Foundation Excavation (DURF), Addressing Block 9 of the Transbay Redevelopment Project Area. Available from the Northwest Information Center, California Historical Resources Information System, Rohnert Park, CA. 


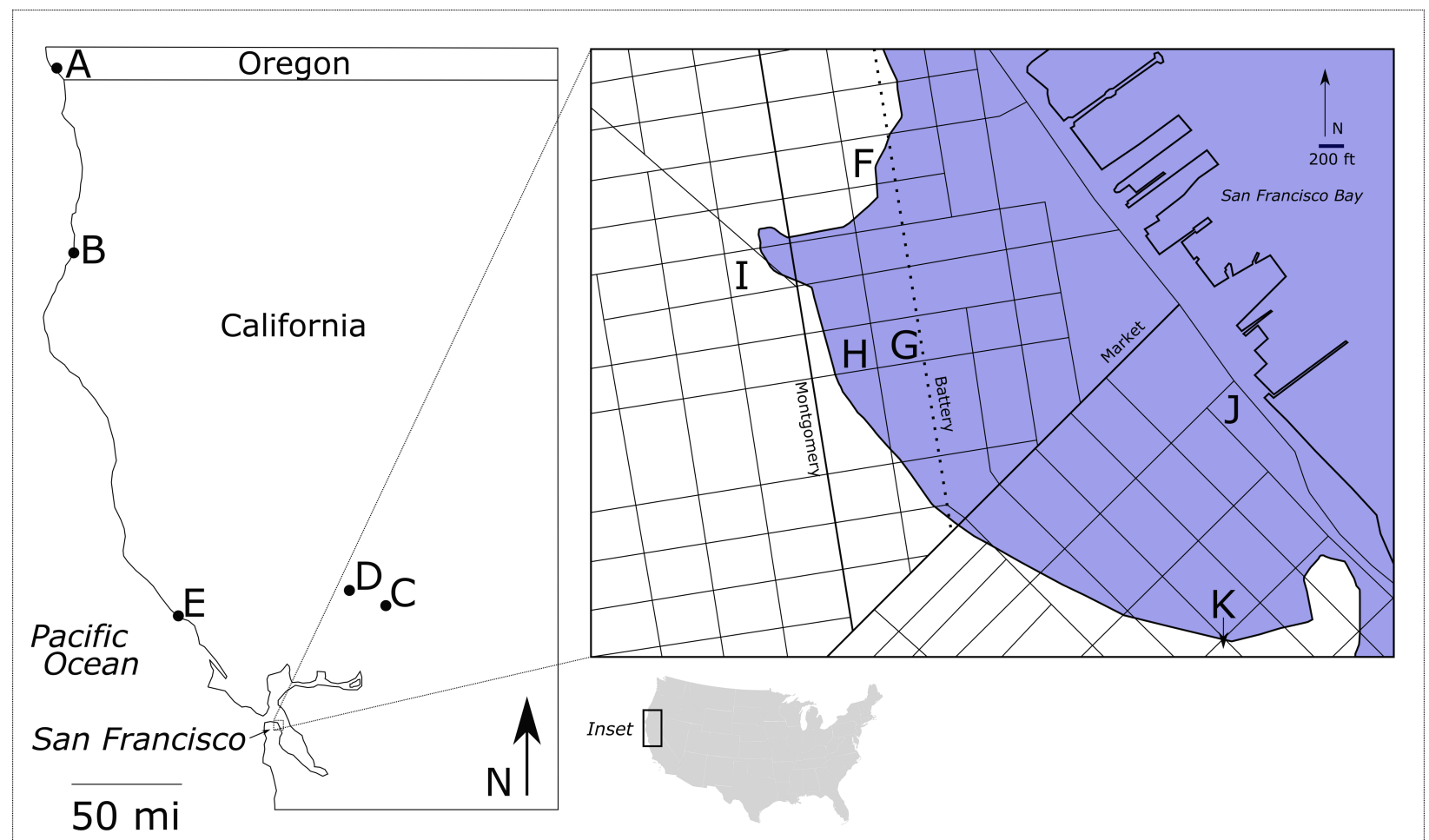

Figure 1. The location of select archaeological sites discussed in text, including Thompson's Cove (CA-SFR-186H). The shaded area represents the approximate extent of the original Yerba Buena Cove during the onset of the Gold Rush in 1848-1849. A: 35-CU-42 (Tushingham and Christiansen 2015), B: HUM-321 (Tushingham and Christiansen 2015), C: Golden Eagle Hotel/Cronin's Oyster Saloon (Schulz 1980), D: Woodland Opera House (Schulz 1984), E: Fort Ross (Lightfoot et al. 1997), F: Thompson's Cove (this study), G: The Hoff Store (Hattori and Kosta 1990), H: 343 Sansome Street (Christenson 1989), I: North Beach Campus (Valente 2012), J: 110 The Embarcadero (Praetzellis 2017) and K: 343 Fremont Street (Praetzellis 2015). 


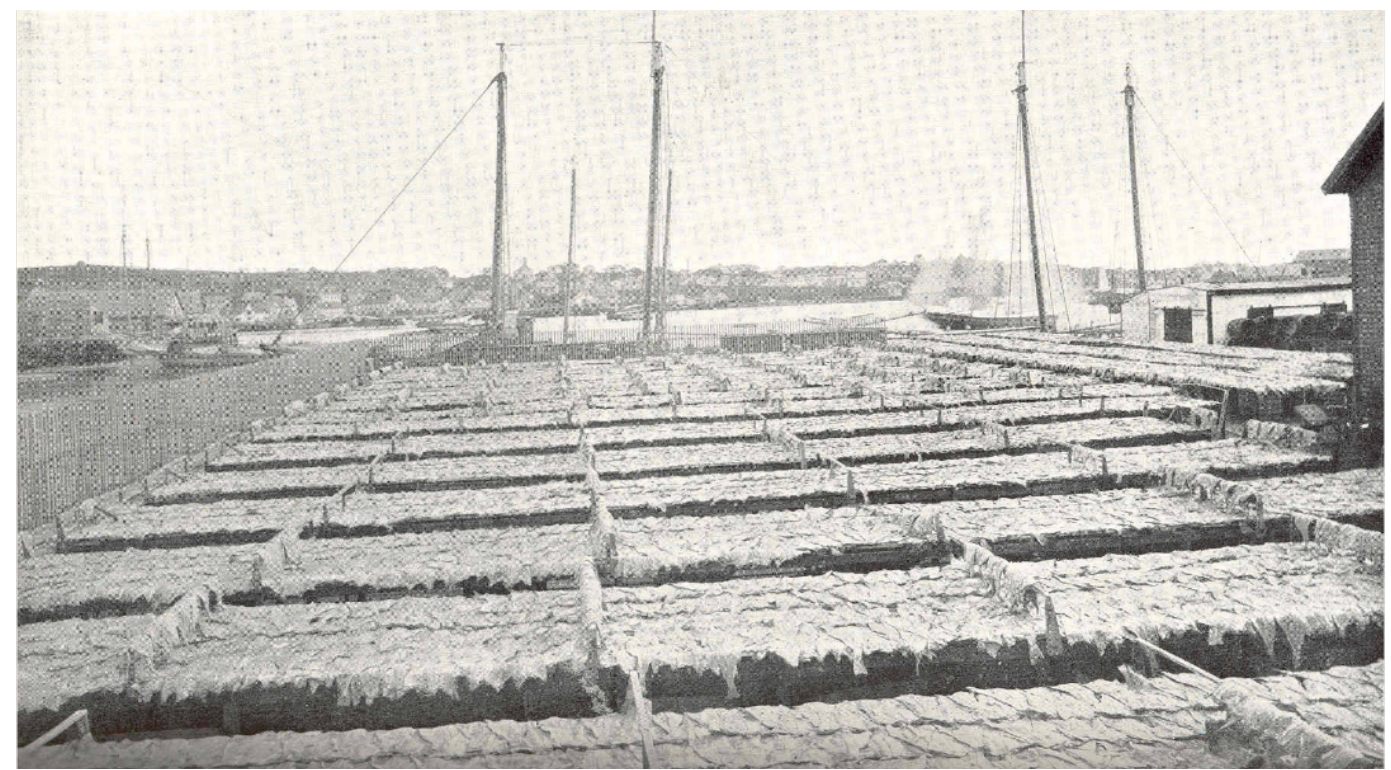

Figure 2. "Drying Codfish in Flake Yard at Gloucester Massachusetts" ca. 1899 by Charles H. Stevenson. Historic photograph courtesy of the University of Washington, Freshwater and Marine Image Bank (\#38918). 


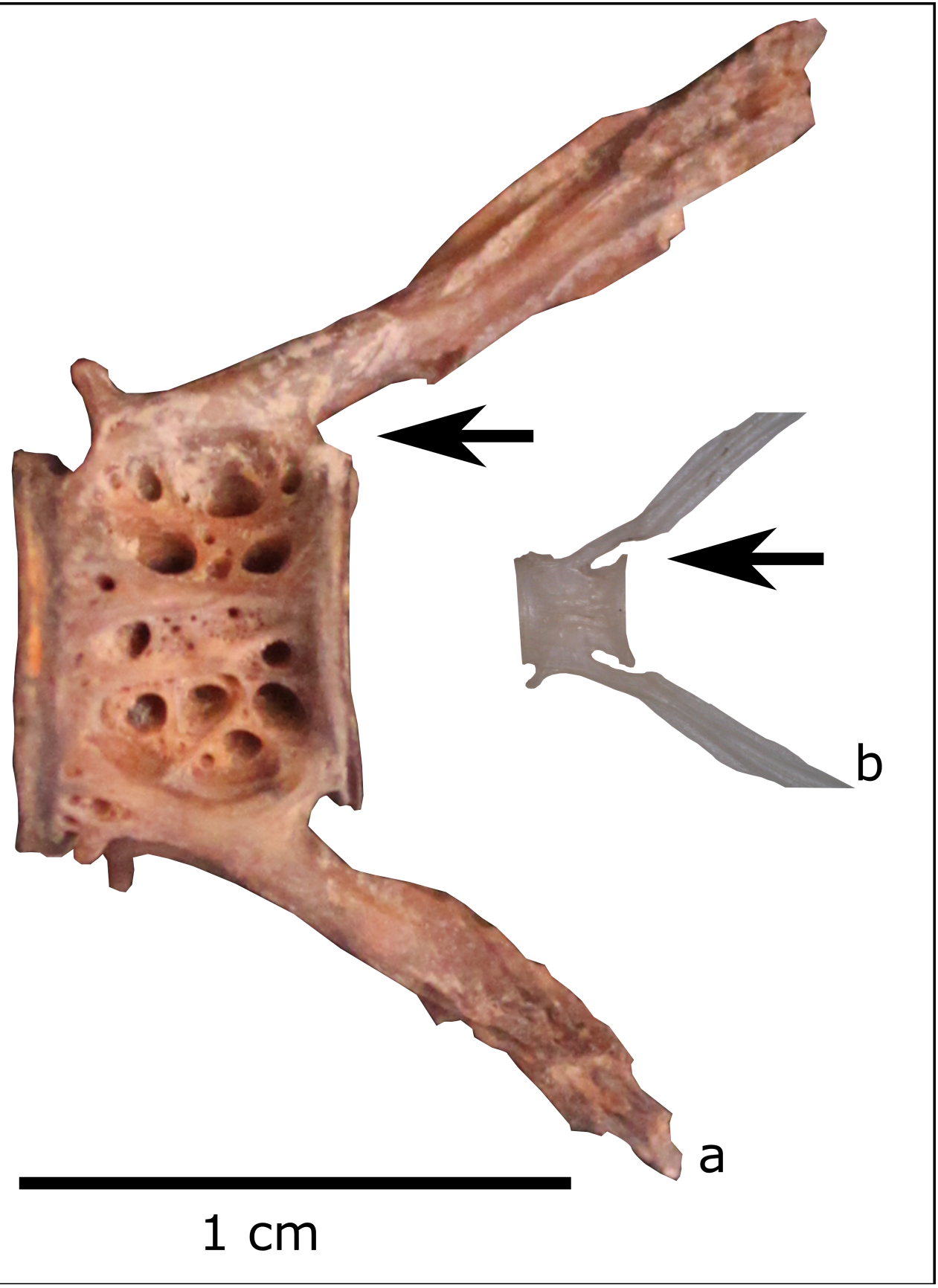

Figure 3. (A) Caudal vertebra (sample 107) from an Atlantic cod at Thompson's Cove (CA-SFR$186 \mathrm{H}$ ) analyzed in this study and (B) Pacific cod caudal vertebra from a contemporary comparative collection, courtesy of Dr. Gabriel M. Sanchez, Department of Anthropology, Michigan State University. Note the differential attachment of the neural and hemal arch bases to the caudal edge of the centrum (see arrows). 


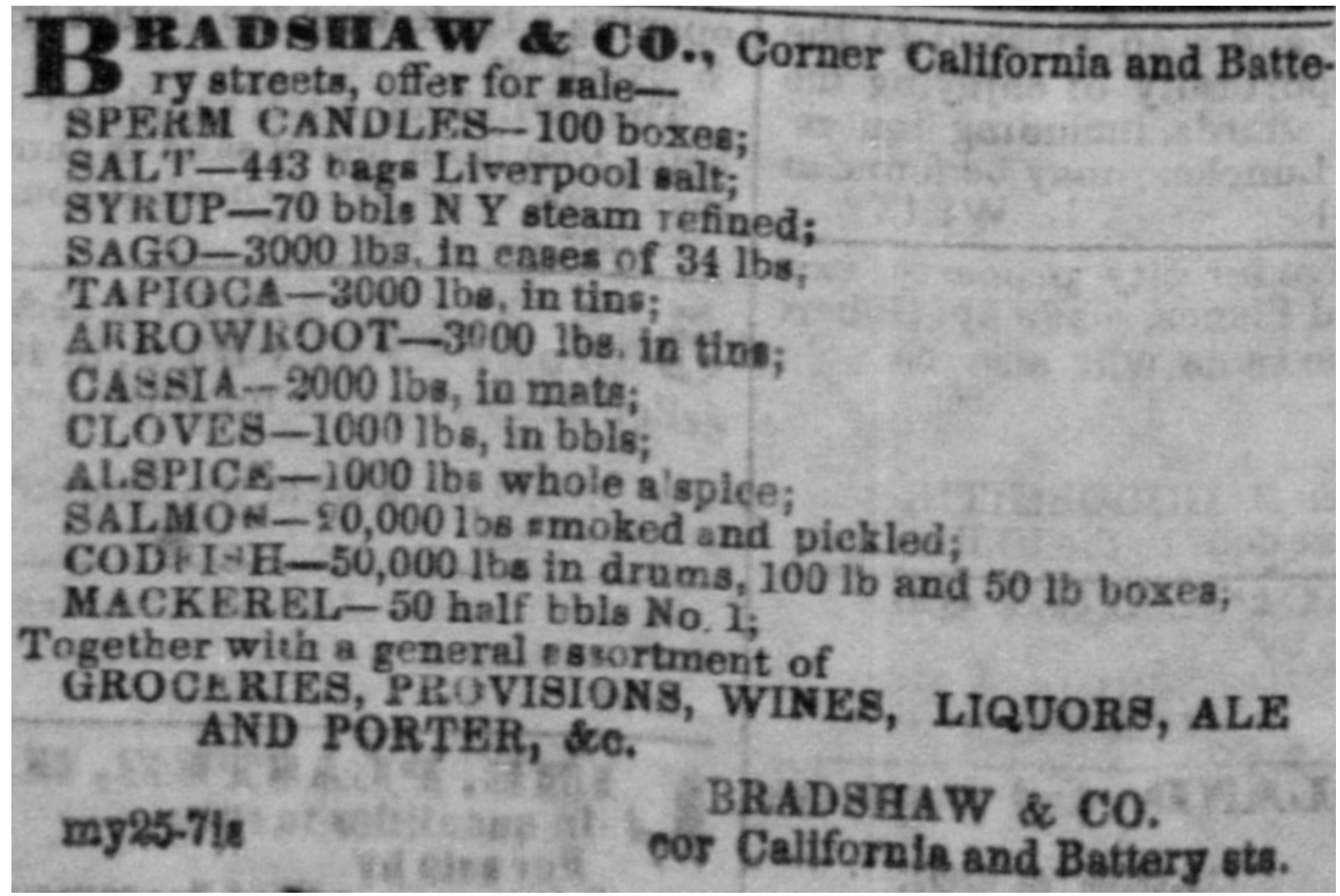

Figure 4. An advertisement for "codfish" at Bradshaw \& Co. from the May 25, 1853, Daily Alta California. This seller was located on the corner of California and Battery streets, approximately five blocks south/southeast of the Thompson's Cove archaeological site. Source: California Digital Newspaper Collection, Center for Bibliographic Studies and Research, University of California, Riverside, http://cdnc.ucr.edu.

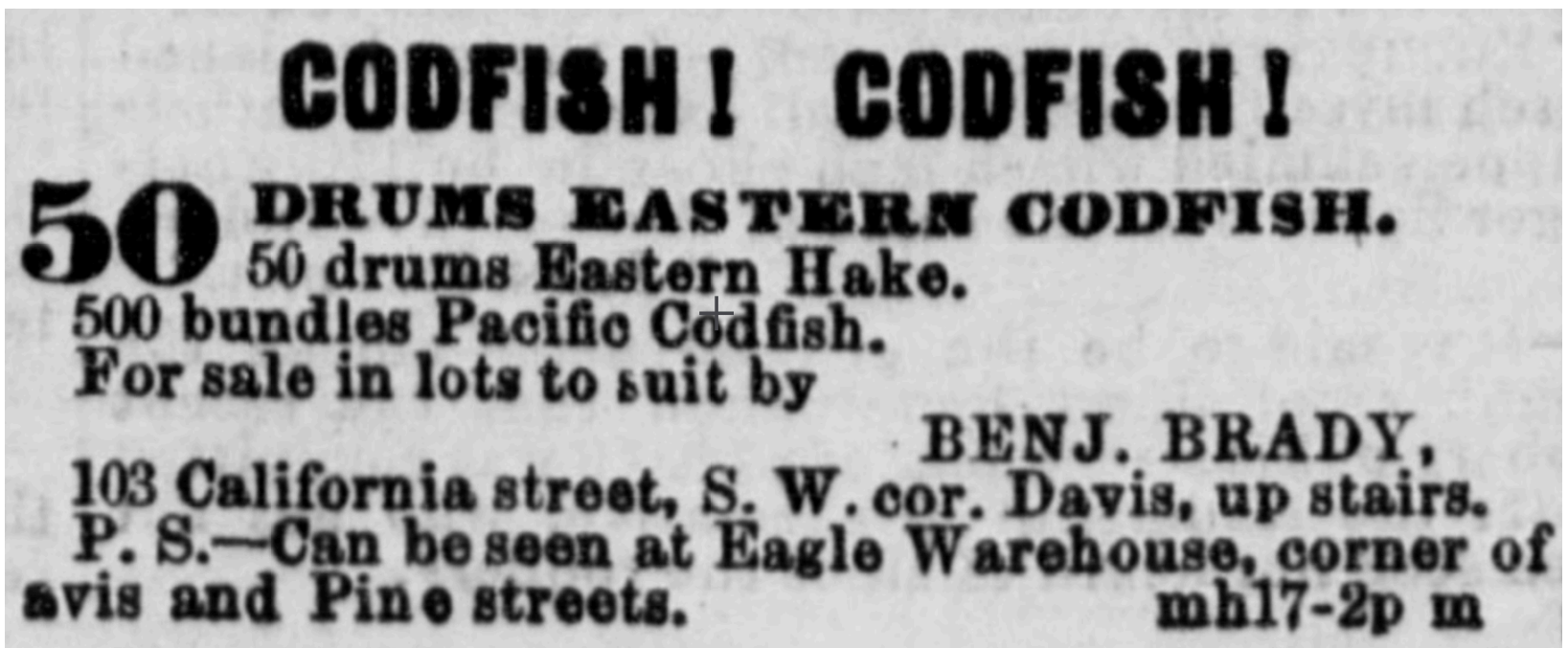

Figure 5. An advertisement for "Codfish! Codfish!” at Benjamin Brady from the April 3, 1868, Daily Alta California. This seller was located at 103 California Street. Source: California Digital Newspaper Collection, Center for Bibliographic Studies and Research, University of California, Riverside, http://cdnc.ucr.edu. 


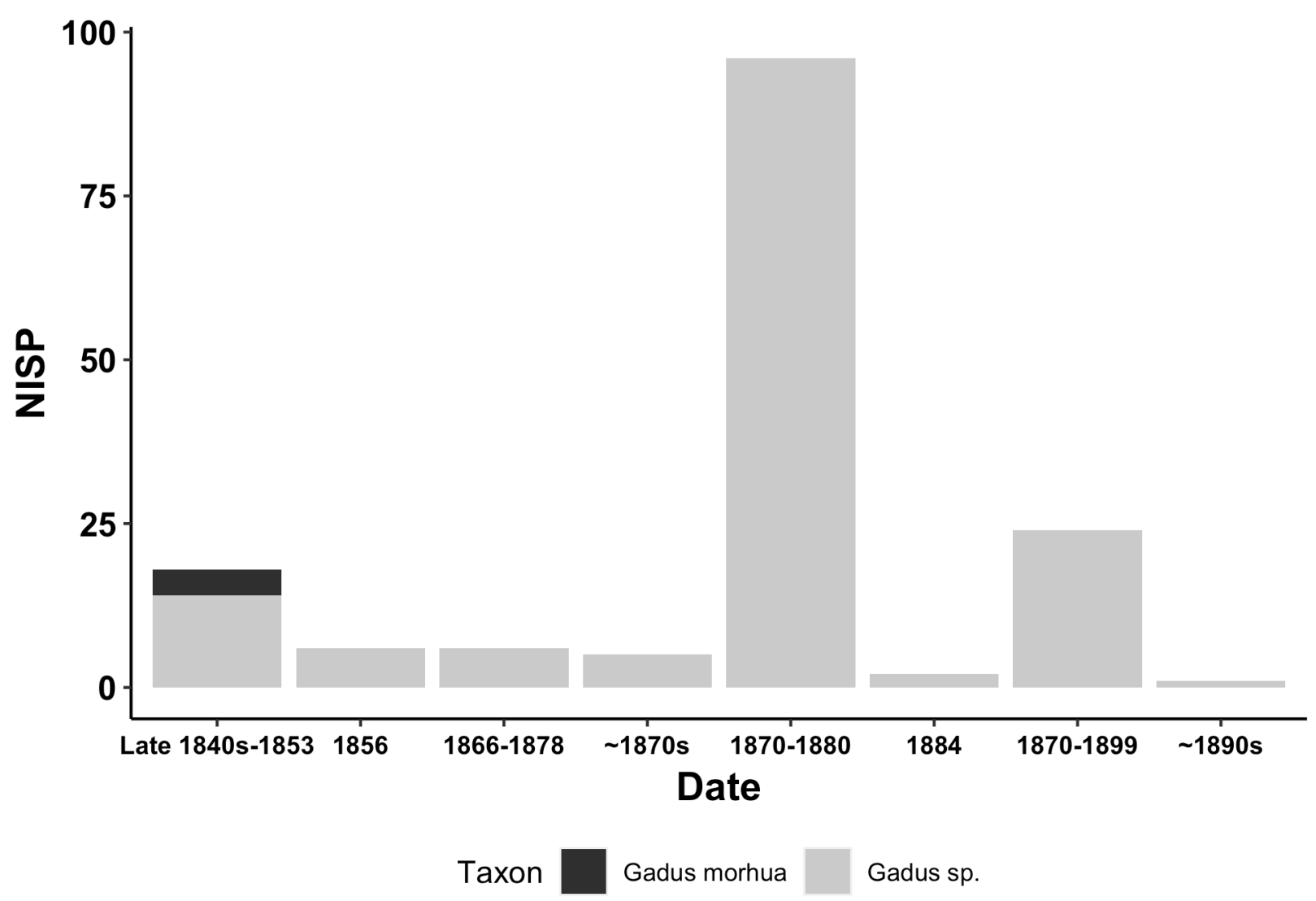

Figure 6. Cod bone abundance (NISP) and taxonomic identifications from sites in northern California. Data sources: Late 1840s-1853 (Thompson's Cove, this study), 1856 (Gold Eagle Hotel; Schulz 1980), 1866-1878 (Cronin's Oyster Saloon; Schulz 1980), 1870s (Gobalet 2014), 1870-1880 (St. Clair and Dobkin 2003), 1884 (Schulz 1984), 1870-1899 (William Self Associates 2013, 2019) and 1890s (KWG, unpublished laboratory notes). Note, all non-aDNA identifications are aggregated into Gadus sp. given uncertainty in their original identifications. For the data and script asso- ciated with this figure, see https://doi.org/10.17605/OSF.IO/WCJD3 
Table 1. Cod importation records from the Daily Alta California between December 1848 and December 1852. For all Daily Alta California newspapers available in the California Digital Newspaper Collection (https://cdnc.ucr.edu/) we reviewed and digitized "Shipping Intelligence" and "Importation" records to identify shipments of cod into San Francisco.

\begin{tabular}{|c|c|c|c|c|c|c|}
\hline $\begin{array}{l}\text { Vessel } \\
\text { Type }\end{array}$ & Vessel Name & $\begin{array}{l}\text { Import } \\
\text { Type }\end{array}$ & Quantity & $\begin{array}{l}\text { Date Imports } \\
\text { Published }\end{array}$ & Vessel Origin & $\begin{array}{l}\text { Days Sailed to } \\
\text { San Francisco }\end{array}$ \\
\hline barque & Helen S. Paige & boxes & 25 & June 14,1850 & Boston & 210 \\
\hline schooner & Lydia & boxes & 41 & July 15,1850 & New York & 135 \\
\hline ship & Thos. W. Scars & boxes & 85 & July 16,1850 & Boston & 143 \\
\hline barque & Archibald Gracie & drums & 20 & July 19,1850 & Boston & 148 \\
\hline barque & Abagun & drums & 20 & July 31,1850 & New York & 180 \\
\hline brig & Eliza Taylor & drums & 47 & August 5, 1850 & Boston & 144 \\
\hline barque & Cuba & drums & 10 & August 15,1850 & Boston & 150 \\
\hline brig & Picard & drums & 28 & September 18,1850 & New Haven & 180 \\
\hline barque & General Taylor & boxes & 55 & October 9,1850 & Boston & 165 \\
\hline barque & Ellen Noyes & boxes & 10 & October 11,1850 & Boston & 165 \\
\hline brig & Victoria & tubs & 36 & November 16,1850 & Liverpool & 190 \\
\hline ship & Gerrone & $\operatorname{kegs}^{1}$ & 18 & November 18,1850 & New Bedford & 197 \\
\hline ship & Cariolanus & boxes & 100 & November 19,1850 & New York & 218 \\
\hline ship & William H. Harbeck & half barrels & 12 & November 25,1850 & New York & 148 \\
\hline barque & Juno & boxes & 50 & November 26,1850 & Boston & 213 \\
\hline schooner & Mary Filkins & boxes & 300 & December 3,1850 & New Orleans & 238 \\
\hline barque & Royal Sovereign & tubs & 20 & January 7, 1851 & Cardiff & 204 \\
\hline barque & Adelaide & drums $^{2}$ & 60 & February 5, 1851 & Halifax & 200 \\
\hline brig & Dracut & drums & 6 & April 2, 1851 & Boston & 160 \\
\hline ship & John Gray & barrels & 20 & April 5, 1851 & Greenock & 175 \\
\hline brig & Acis & tubs & 33 & April 21, 1851 & Adelaide & 93 \\
\hline barque & Jessie Byrne & barrels & 29 & May 23, 1851 & Cork & 147 \\
\hline barque & Walter Claxton & drums & 25 & June 14,1851 & Boston & 155 \\
\hline barque & Margaret Hugg & pounds & 300 & July 1, 1851 & Baltimore & 182 \\
\hline
\end{tabular}




\begin{tabular}{|c|c|c|c|c|c|c|}
\hline brig & Charran & boxes & 2 & July 2,1851 & New Orleans & 175 \\
\hline brig & Mary Helen & pounds & 1000 & July 16, 1851 & Santa Barbara & 17 \\
\hline clipper ship & Witch of the Wave & boxes $^{3}$ & 22 & September 21,1851 & Boston & 122 \\
\hline brig & Wyandot & cases & 190 & January 3, 1852 & Honolulu & 16 \\
\hline \multirow[t]{3}{*}{ barque } & Ala & boxes & 100 & July 5,1852 & Boston & 155 \\
\hline & & half drums & 100 & & & \\
\hline & & drums & 25 & & & \\
\hline ship & Eastern State & drums & 50 & July 13,1852 & New York & 150 \\
\hline ship & Michael Angelo & boxes & 200 & August 3,1852 & New York & 148 \\
\hline clipper ship & Statflordshire & drums & 61 & August 14, 1852 & Boston & 101 \\
\hline ship & Shooting Star & boxes & 60 & August 18, 1852 & Boston & 105 \\
\hline ship & David Cross & casks & 70 & September 6, 1852 & Valparaiso & 79 \\
\hline clipper ship & Sovereign of the Seas & large cask & 28 & November 16,1852 & New York & 103 \\
\hline clipper ship & Southern Cross & drums & 30 & November 29, 1852 & Boston & 153 \\
\hline clipper ship & Onward & boxes & 150 & December 2,1852 & Boston & 120 \\
\hline clipper ship & Syren & boxes & 50 & December 24, 1852 & New York & 118 \\
\hline
\end{tabular}

1This shipment is of "codfish tongues"

${ }^{2}$ This shipment is of "dried codfish"

${ }^{3}$ This shipment is of "cod liver oil" 
Table 2. Fish specimens recovered from several Gold Rush-era and later sites throughout San Francisco and Sacramento, California

\begin{tabular}{|c|c|c|c|c|c|c|c|c|c|c|c|c|}
\hline Taxon & Common Name & $\begin{array}{l}\text { Dates: } \\
\text { Site: }\end{array}$ & $\begin{array}{c}1840 \mathrm{~s}- \\
1853 \\
\text { TC }\end{array}$ & $\begin{array}{c}1840- \\
1857 \\
\text { NBC }\end{array}$ & $\begin{array}{r}1851 \\
343 \mathrm{~S} .\end{array}$ & $\begin{array}{c}1850- \\
1880 \\
\text { WLL }\end{array}$ & $\begin{array}{c}1852- \\
1857 \\
\text { NDP }\end{array}$ & $\begin{array}{l}1856 \\
\text { GEH }\end{array}$ & $\begin{array}{c}\text { Mid- } \\
1860 \mathrm{~s} \\
110\end{array}$ & $\begin{array}{c}1862- \\
1878 \\
343 \mathrm{~F} .\end{array}$ & $\begin{array}{c}1866- \\
1878 \\
\text { COS }\end{array}$ & $\begin{array}{c}1870 s- \\
1880 \mathrm{~s} \\
\text { CFP }\end{array}$ \\
\hline Rajiformes & Skates and rays (not bat ray) & & 1 & & & & & & & & & \\
\hline Acipenser sp. & White or green sturgeon & & 17 & & & & & & & & 18 & \\
\hline \multirow[t]{2}{*}{ Clupeidae } & Herring/Sardine & & 57 & & & & & & & & & \\
\hline & Scales & & 27 & & & & & & & & & \\
\hline Clupea pallasii & Pacific herring & & 2 & & & & & & & & & \\
\hline Oncorhynchus sp. & Pacific salmon and steelhead & & 21 & & & & & & & & & \\
\hline Salmonidae & Trout and salmon & & & & & & & & 4 & & & \\
\hline Cyprinidae & Minnow/Carp & & 2 & & & & & & & & & \\
\hline Ptychocheilus grandis & Sacramento pikeminnow & & 11 & & & & & & & & & \\
\hline Catostomus occidentalis & Sacramento sucker & & 1 & & & & & & & & & \\
\hline Gila crassicauda & Thicktail chub & & & & & & & & & & 26 & \\
\hline Gadus sp. & Atlantic or Pacific cod & & 18 & & & & & 6 & & & 6 & 9 \\
\hline Gadus macrocephalus & Pacific cod & & & & & & & & & & & 87 \\
\hline Scorpaenidae & Rockfishes & & & & & & & & & & 13 & \\
\hline \multirow[t]{2}{*}{ Sebastes sp. } & Rockfishes & & 19 & & & & & & & 2 & & 30 \\
\hline & Scales & & 5 & & & & & & & & & \\
\hline Pleuronectiformes & Flatfish & & & & & & & & & 5 & 2 & \\
\hline Psettichthys melanostictus & Sand sole & & & & & & & & & & & 1 \\
\hline Ophiodon elongatus & Lingcod & & 1 & & & & & & & & 12 & \\
\hline Sciaenidae & Drums and croakers & & 1 & & & & & & & & & \\
\hline Atractoscion noblis & White seabass & & & & & & & & & & 2 & \\
\hline Embiotocidae & Surfperches & & 13 & 1 & & & $\mathrm{X}$ & & 2 & & 4 & \\
\hline Embiotoca sp. & Black or striped surfperch & & 3 & & & & & & & & & \\
\hline Scomber sp. & Mackerel & & & & & & & & & & 3 & \\
\hline Scomber japonicus & Pacific chub mackerel & & 14 & & & & & & 2 & & & \\
\hline \multirow[t]{2}{*}{ Actinopterygii } & Ray-finned fishes & & 456 & 1 & 45 & 49 & $\mathrm{X}$ & & & & & 178 \\
\hline & Scales & & 894 & & & & & & & & & \\
\hline
\end{tabular}


Notes: $\mathrm{X}=$ present. TC $=$ Thompson's Cove (Conrad et al. 2015a), NBC = North Beach Campus (Valente 2012), $343 \mathrm{~S} .=343$

Sansome Street (Christenson 1989), WLL = Wing Lee Laundry (Pastron and Beevers 2003), NDP = Notre Dame Plaza (Ambro 2003), GEH/COS = Golden Eagle Hotel/Cronin's Oyster Saloon (Schulz 1980), $110=110$ The Embarcadero (Praetzellis 2017), 343 F. = 343 Fremont Street (Praetzellis 2015), CFP = Central Freeway Project (St. Clair and Dobkin 2003) 
Table 3. Cod (Gadus sp.) specimens and elements from Thompson's Cove (CA-SFR-186H)

\begin{tabular}{llll}
\hline Element & Feature 25 & Feature 15 & Feature 7 \\
\hline Undetermined vertebral fragment & 5 & & 2 \\
Caudal vertebrae & 3 & 2 & 1 \\
Neural spines & 2 & & 3 \\
\hline
\end{tabular}


Table 4. Selected specimens, provenience, and results for ancient DNA analysis

\begin{tabular}{llllll}
\hline Catalogue No. & Feature & Context & Specimen & $\begin{array}{l}\text { Subsampled } \\
\text { amount (mg) }\end{array}$ & aDNA Species \\
\hline 107 & 25 & Courtyard-Area 4, Trench 1 & Vertebra & 41.2 & Gadus morhua \\
108 & 25 & Courtyard-Area 4, Trench 1 & Caudal vertebra & 55.8 & Gadus morhua \\
111 & 25 & Courtyard-Area 4, Trench 1 & Vertebra & 45.5 & Gadus morhua \\
113 & 25 & Courtyard-Area 4, Trench 1 & Caudal vertebra & 37.4 & Gadus morhua \\
870 & 15 & Quad H7 (East 1/2) North 16-32 East 47-53 & Caudal vertebra & 54.5 & Gadus sp. \\
\hline
\end{tabular}

